\title{
Developing A Digital Knowledge Platform Based on Educational and Technical Standards to Design Auto-Produced E-Learning Objects in Sultanate of Oman
}

\author{
Authors \\ Dr. Nader Shemy ${ }^{1}$, Dr. Walid Aboraya ${ }^{2}$, Dr. Sameh Said ${ }^{3}$, Dr. Muna Alkalbani ${ }^{4}$, Naglaa \\ Shehata ${ }^{5}$, Baraa Abdelhady ${ }^{6}$
}

\begin{abstract}
E-learning is the use of digital technologies to increase classroom engagement such as, the Internet, interactive multimedia, and other means. This study aimed to measure the effectiveness of a digital knowledge platform (generator) based on the educational and technical standards which allow Omani teachers, interested persons and other stakeholders to design and produce e-learning objects by their own without the need to have high educational and technical skills. It only requires the teacher to add the educational content, including the activities, evaluations, and auxiliary media to that generator in light of a specific mechanism, so that at the end and within a very limited time and without any effort that may represent a burden on teachers, they will eventually obtain a stand-alone learning object, this object will be automatically uploaded to the platform and will be available to all registered users in the generator, and the teachers can re-use this object for any other purposes and in any other educational context. To examine the platform, a questionnaire was distributed to a group of 100 Omani teachers to assess the ease of use, accessibility, and efficacy from their point of view. The questionnaire consisted of seventeen statements that reflected the study's objectives. In terms of simplicity of use, accessibility, and efficacy, it was found that most teachers $(88 \%)$ agreed about the easiness and usefulness of the generator. This indicates that instructors are in desperate need of and ready to utilize the proposed generator to enhance the learning process.
\end{abstract}

Keywords: E-learning, Digital Generator, Oman Education Community, Learning Objects and Learning Theories.

\footnotetext{
${ }^{1}$ Main Researcher, Arab Open University, Oman

${ }^{2}$ Arab Open University, Oman

${ }^{3}$ Sultan Qaboos University, Oman

${ }^{4}$ Ministry of Education, Oman

${ }^{5}$ Helwan University, Egypt

${ }^{6}$ Dar Al-Fatwa, Egypt
} 


\section{Developing A Digital Knowledge Platform Based on Educational and Technical Standards to Design Auto-Produced E-Learning Objects in Sultanate of Oman}

\section{Introduction}

Many educators and researchers are interested in online courses to enhance and improve student learning outcomes while battling the scarcity of resources, facilities, and equipment, especially in higher education institutions. Thanks to the Internet, we were able to provide more flexible access to content and training anytime and anywhere, and so online learning has grown in popularity (Castro, 2019). It is important that researchers consider and investigate the effectiveness of online learning, as it can improve access to education and training, improve teaching and learning quality, and help institutions to preserve competitive benefits for students in these changing markets. This has led to the complete use of IT to improve the teaching and learning process and to deliver to more students at a lower cost (Peled, 2000 in Hafizah \& Kamil, 2009). E-learning can therefore improve the quality of education and learning.

Fig. 1 shows the types of connections between the interactive tools of the e-learning environment, the teacher, and the student which include (information distribution, communication tools, interaction tools, and monitoring tools). 




Figure (1) relationship between e learning plateform, teacher, and student

(Todor Vlad, Dan Pitica , Jano Rajmond,2012)

Onofrei \& Ferry,(2020) define learning object as one of the forms of e-learning and a digital learning resource that enables the user to access it via the Internet, and it can also be reused in different educational situations and enables the user to employ it according to the requirements of the educational situation. As for (Mourão \& Netto, 2019), they defined it as a set of relatively small units that can be used more than once, it is used on a set of educational materials organized according to specific educational foundations, it includes the goals and outputs to be reached and the appropriate assessment methods and is kept in an accessible database anywhere and anytime.

There are many features that characterize learning objects, as they have an important role in the educational process, and they have a great impact on the educational 
aspect, among the most important characteristics of learning objects are as follows (Crisan, 2020), (Dolgopolovas, 2018), (Spitz, 2020), (Goodsett, 2020):

- Ease of access, and the extent of this ease lies in that, digital objects are classified and numbered in the database and are available to everyone, whether the teacher or the learner.

- Independence, as it is independent and can be used without any software.

- Reuse, learning objects are characterized as they can be reused at any time whenever the educational situation requires it.

- A digital resource, which the teacher or learner can employ in virtual classes, as it is one of the most prominent educational electronic resources.

- It is one of the most important foundations for the user to be able to build his experiences and educational activities.

- Merge, it is easy to merge and group educational objects together and create digital educational curricula.

- Learning objects are characterized by privacy, which allows considering individual differences between students and their educational levels.

- Availability, one of the most important characteristics of learning objects is that they consider the tendencies and desires of the learner, as they are available whenever the need for them and at the time and place chosen by the learner.

Considering the great importance that results from the use of digital learning objects, the researchers emphasized that providing the opportunity for teachers with limited skills in the field of design and production to produce the learning objects by themselves is very important, as it will result in the design and production of hundreds of learning objects that can be effectively employed in the learning context.

\section{International Journal of Curriculum \& Technological Education}


المجلد الخامس (العدد (السادس)

ديسمبر 2021
المجلة الدولية للمناهج والتربية التكنولوجية

IJCTE

It has a significant impact on teachers' performance, and at the same time, a significant positive impact on achieving the intended learning outcomes in any course. This is what the current research seeks to reach, which is to design an easyto-use generator to produce learning objects by teachers without any technical requirements beyond their capabilities.

\section{Literature Review}

Many researchers investigated the need for and importance of learning from digital content that is related to their curriculum within an e-learning system. Such studies are related to learning objects and digital repositories that can be made available to enhance students' learning and teachers' performance and allow us to implement an integrated e-learning system through which students can receive knowledge easily. Among those studies is the study of Luaran (2014) which aimed to investigate the effectiveness of using e-learning among secondary school students. Data were collected from 45 students studying at three schools in Selangor. The data were analyzed using SPSS. Most of the respondents had been exposed to e-learning, and one of the reasons they preferred it was because it gave them more freedom in choosing between instructor-led and self-study courses, as well as the ability to learn at any location and time. They also agreed that one of the drawbacks of utilizing eLearning is that it eliminates the need for face-to-face connection with their peers.

Li-Ling Chen (2016) presented a model for effective online instructional design and Prasetya (2021) introduced an online project-based collaborative learning using ADDIE model.

In the Kingdom of Saudi Arabia, Alkhalaf (2012) investigated the effects of elearning technologies on university students. He argued that measuring the impact 
of e-learning systems on learners is critical to developing relevant and efficient elearning frameworks. Students from two different colleges in Saudi Arabia were polled about their experiences with existing e-learning programs. The assessment approach was based on the "Success/Impact Measurement framework," which has been used effectively in research on e-learning, e-health, and e-government.

Darabi et al. (2013) studied how successful online conversation methods are. They argued that online learning programs are a significant technique for increasing educational institutions' accessibility and flexibility, improving both students' and institutions' perspectives. From the perspective of students, the ease of online learning is especially important for adults with numerous obligations and a high quality of life; as a result, online learning may enable people return to school and finish extra training that is not part of their daily routines.

Sek et al. (2012) wanted to know how successful the learning components were in a course on digital systems, and the results indicated that there were statistically significant variations in performance and accomplishment for students who used the learning objects.

Through the knowledge of the selected institutions and their willingness, Kamba (2009) evaluated and addressed the difficulties, obstacles, and benefits of e-learning adoption in Nigeria. This paper also examined the elements that contribute to Nigeria's future e-learning growth. The study employed survey methodologies, and the questionnaire was the sole tool used to gather data. The conclusions of the study demonstrate 12 viable replies from the 18 institutions, namely three universities from each geographical zone. They were chosen from a variety of specialist areas. These polls received a 67 percent response rate. 
المجلد الخامس (العدد السادس)

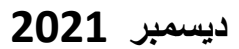

المجلة الدولية للمناهج والتربية التكنولوجية

IJCTE

Topali \& Mikropoulos (2021) conducted an exploratory analysis to determine preuniversity instructors' understanding of open-source educational materials (OER). Data were collected from 99 teachers in order to determine their attitudes on opensource educational resources, the potential for their usage, and the challenges they may encounter in educational institutions. The study stated that there are certain hurdles to collecting, modifying, and implementing educational resources from open source, and that digital repositories for pre-university education should be developed because of their potential to improve students' performance.

Marciniak (2014) described how to establish digitalized educational content repositories and how to use the technologies to make them more reusable. The method included a set of guidelines for arranging educational materials as well as a technique to provide clear educational interpretation to portions of materials using the "Universal Curricular Taxonomy System." The specific software knowledge repository tool, which was built to store and process educational information with the possibility of reuse in multiple educational situations, is an important part of the strategy given. This application allowed users to create single- or multi-topic repositories, as well as distributed repositories.

Individual Saudi-Arabia students assessed the influence of an e-learning system, according to Alkhalaf, Drew, and Alhussain (2012). It was built on DeLone and McLean's IS Success/Impact Measurement Framework, which was expanded to Gable, Sedera, and Chan in 1992 (2008). This article demonstrates that using a learning system has a favorable impact on an individual's impact. Importantly, the findings corroborated number of prior studies on the effects of e-learning systems on people. 
To address shortcomings in the National e-Learning Center's model (NELC), Abdelfattah, Emam, and Abdel-hady (2019) reported the creation of a new model for the production process of e-learning courses. Arbitration, development, e-course review, and e-course activation are the four phases of the proposed model. The data showed that the suggested model's e-course development process takes an average of 4 weeks rather than 12 months in the NELC model.

Derntl \& Calvo (2011) looked at how usability of instructional design patterns for technology-enhanced learning may be improved by combining patterns with readyto-use resources as part of an e-learning framework approach. The researchers presented two different ways for creating an e-learning framework: (1) 'Extension' method, which provides pattern-based, bespoke LMS components; and (2) 'Facade' approach, which allows pattern-based reuse of existing LMS components. The effectiveness and benefits of e-learning frameworks are demonstrated by implementations of both methodologies.

It is obvious that many attempts and institutional and personal efforts have been made in the past to design and develop digital learning objects and then make them accessible to students at various stages of education, but these attempts and efforts are still in the early stages and are not optimally developed due to the lack of a unified paradigm in the design and creation based on educational and technological standards. As a result, students must be given the opportunity to actively participate in their own learning process by providing a variety of educational resources by using an e-learning framework with knowledge repositories to suit all students and provide comprehensive, integrated, and continuous teaching and learning results that meet the future needs of students community. Although this will be a good solution,

\footnotetext{
International Journal of Curriculum \& Technological Education https://ijcte.journals.ekb.eg

Online ISSN: 2735-511X 
developing learning objects related to local curriculum will stay a challenge, and this is what the current study is trying to solve.

Regarding standards for designing and producing learning objects, there are many standards that can be relied upon in this regard, provided that they are repurposed in line with the characteristics of the education community in the Sultanate of Oman. Vargo, Nesbit, Belfer and Archambault (2003) developed a Learning Object Review Instrument or LORI to evaluate learning objects. The LORI approach uses the following 10 criteria when examining learning objects:

- Presentation: Aesthetics

- Presentation: Design for learning

- Accuracy of content

- Support for learning goals

- Motivation

- Interaction: Usability

- Interaction: Feedback and adaptation

- Reusability

- Metadata and interoperability compliance

- Accessibility.

More recently, the Collaborative Learning Object Exchange (CLOE) based at the University of Waterloo in Ontario, Canada, has developed a peer review process for material developed through a collaborative initiative among the university and college sectors in Ontario for inclusion in a provincial learning object repository. The CLOE criteria are as follows (Nesbit \& Li, 2004):

- The content of the learning object is accurate.

- The use of technology is appropriate for this content. 
- The content is presented clearly and professionally (spelling/grammar, et cetera).

- Appropriate academic references are provided.

- Credits to creators are provided.

- There are clear learning objectives.

- The learning object meets the stated learning objectives.

-The target learners are clearly identified (academic level addressed/technical ability/demographics).

- There are clear instructions for using the learning object.

- The technology helps learners to engage effectively with the concept/skill/idea.

- The learning object provides an opportunity for learners to obtain feedback within or outside the learning object.

- The author provides evidence that the learning object enhances student learning.

- Pre-requisite knowledge/skills, if needed, are identified.

- The learning object stands alone and could be used in other learning environments.

- The learning object is easy to use (i.e., navigation, user control).

- The author indicates whether the learning object is accessible for learners with diverse needs.

- Technical requirements for the learning object are provided.

\section{Proposed Model}

This study will rely on the descriptive and analytical approach as follows:

First: Review and analysis of relevant research and studies, as well as regional and global experiences in the subject of the study, which was dealt with in the previous section. Second: Analyzing the status quo in educational institutions in the Sultanate of Oman and some Arab countries to determine both the knowledge and skills of the 
available human resources, the technological infrastructure, the nature of the curricula at different levels of study, the characteristics of the learners, ...). Third: Setting the technical and educational standards necessary to develop the Omani platform for digital knowledge and learning objects of various levels and patterns in line with the outputs of the previous paragraph. Fourth: Reaching a proposed perception of the Omani platform for digital knowledge from the side of educational and technical design and the mechanism of work based on self-production regardless of the technical skills of the users, and dependent at this stage on the foundations and principles of the relevant learning theories. Fifth: Developing and making available the "Omani Digital Knowledge Platform" as a beta version and working with a sample of teachers and interested persons to try it out and clarify any obstacles that need any modifications. Sixth: Making the amendments received from the target sample after analyzing, interpreting, and evaluating them. Seventh: Accessing to the final version of the platform and making it fully available to the target audience and starting its extended use in coordination with the relevant authorities.

The researchers believe that learning objects should be designed and developed to be consistent with the nature of the educational content of the subjects at that educational stage in order to achieve the intended learning outcomes for each of those subjects, and to emphasize that these objects reflect the concept of interaction between the student and the content, by providing content in different styles. For the traditional accepted style, the content presentation style encourages all students to interact with it through processes of knowledge, with the provision of activities and exercises that complement the learning process, and there is a wide scope for selfevaluation of each student's learning level after completing the learning of each object. 
Figure 2 shows the choice of the right eLearning methods that depended entirely on the proper analysis of the organization, the nature of the public and its methods of cooperation. You may want to think about implementing all the analysis, interpretation, and extraction of targeted advantages of choosing the right eLearning methods to meet your needs when you plan your next eLearning course. It does not only simplify and enhance the development process, but also gives your audience a better experience in e-learning.

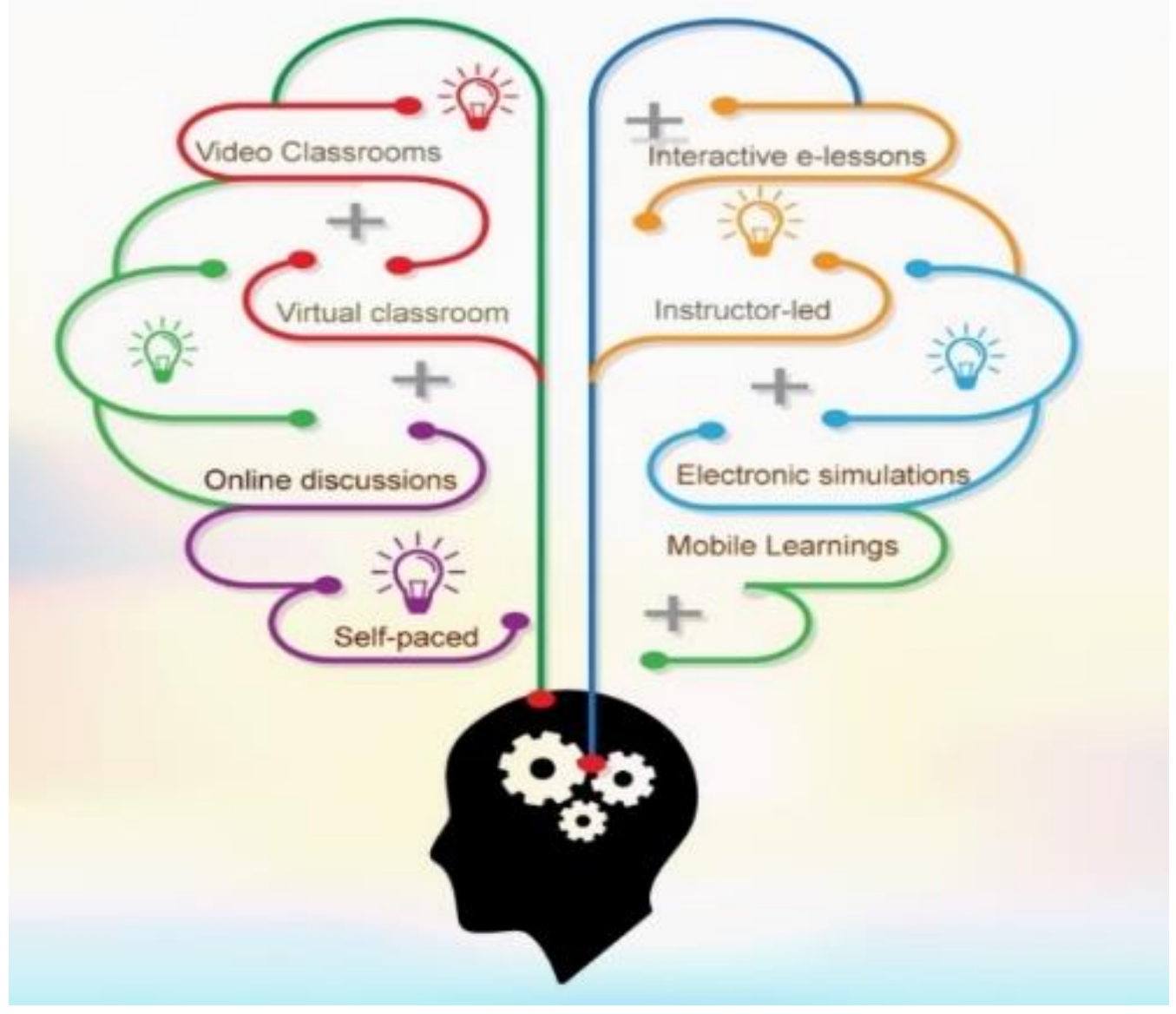

Figure 2 The Right elements of eLearning Methods

Amit Soni G., 2015, https://elearningindustry.com/choosing-right-elearningmethods-factors-elements 
Finally, the researchers were able to develop a digital learning object generator as shown in the following figure 3 :

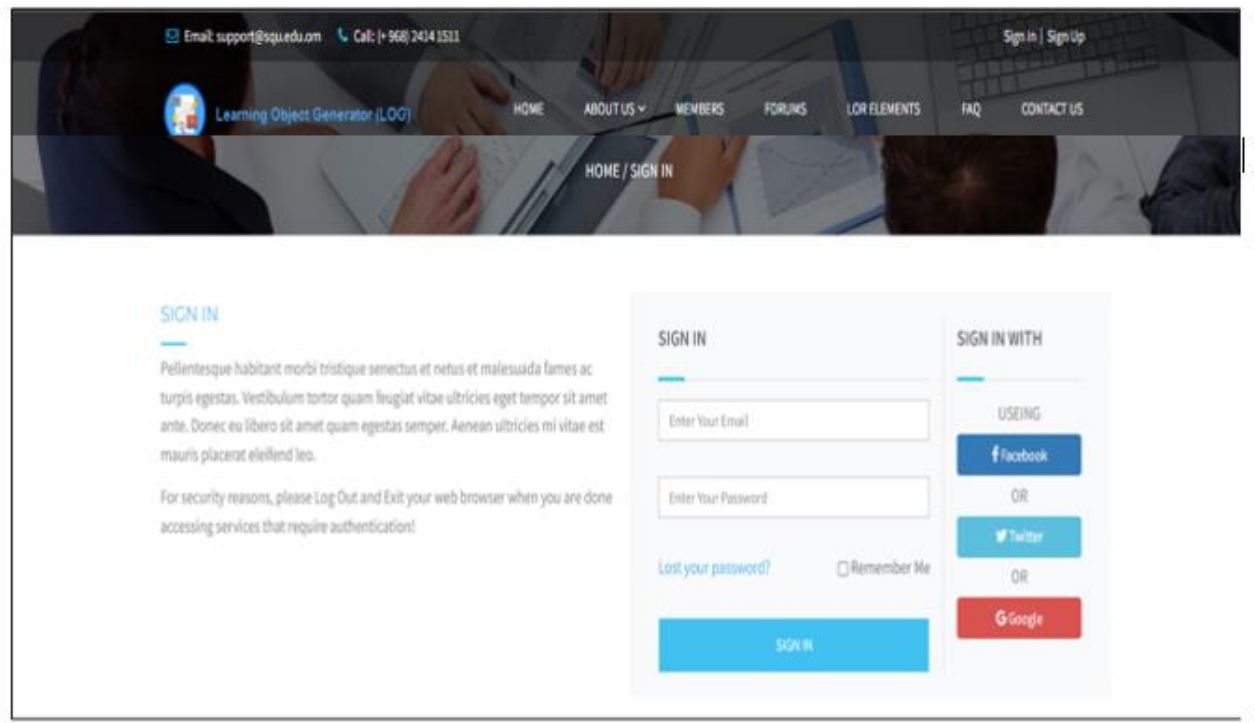

Figure 3 The main interface for LOs Generator

\section{Methodology}

\subsection{Participants}

The current study used a descriptive technique to assess the learning objects generator that was created so that teachers in Omani schools could easily produce learning materials linked to the curriculum they are teaching. To do so, 100 teachers were chosen at random to evaluate their experience using the newly built generator.

\subsection{Research tool}

The researchers created a questionnaire to gather data from teachers regarding the simplicity of use, accessibility, and usefulness of the produced learning objects 
generator after they had used it. The questionnaire had 17 items and was designed using five-point Likert scales. To test the questionnaire's validity, experts in the field were consulted. The survey was piloted on 15 teachers with varied years of experience to ensure its validity. The Cronbach alpha coefficient of the scale was found to be (0.81), indicating that it is reliable.

\section{Results and Discussion}

The simplicity of use, accessibility, and usefulness of the digital repository, as well as the degree of its reception and satisfaction from the teachers' perspective, were measured using a questionnaire administered to a random sample of one hundred teachers in the post-basic education level.

\section{Table 1 Teachers' views about the learning objects generator}




\begin{tabular}{|c|c|c|c|c|c|c|c|}
\hline 1-Strongly Disagree $\quad$ 2- Disagree & $3-\mathrm{N}$ & utral & & Igree & $5-5$ & rongly & Agree \\
\hline Question & SD & D & $\mathbf{N}$ & $\mathbf{A}$ & SA & $\begin{array}{l}\text { Me } \\
\text { an }\end{array}$ & $\begin{array}{c}\text { STD } \\
\text { V }\end{array}$ \\
\hline $\begin{array}{l}\text { The generator can export } \\
\text { learning objects in different } \\
\text { formats }\end{array}$ & $4 \%$ & $6 \%$ & $4 \%$ & $60 \%$ & $26 \%$ & 4.33 & 1.06 \\
\hline $\begin{array}{l}\text { There is an accessible space for } \\
\text { communication among teachers }\end{array}$ & $8 \%$ & $11 \%$ & $6 \%$ & $39 \%$ & $36 \%$ & 3.86 & 1.27 \\
\hline $\begin{array}{l}\text { The learning objects generator } \\
\text { will be useful for teachers }\end{array}$ & $5 \%$ & $2 \%$ & $3 \%$ & $58 \%$ & $32 \%$ & 4.36 & 1.01 \\
\hline $\begin{array}{l}\text { Teachers can easily share good } \\
\text { practices }\end{array}$ & $\begin{array}{l}11 \\
\%\end{array}$ & $8 \%$ & $11 \%$ & $44 \%$ & $26 \%$ & 3.83 & 1.36 \\
\hline $\begin{array}{l}\text { I think that the learning objects } \\
\text { generator will solve the teaching } \\
\text { and learning problems I am } \\
\text { facing. }\end{array}$ & $\begin{array}{l}11 \\
\%\end{array}$ & $2 \%$ & $2 \%$ & $62 \%$ & $23 \%$ & 4.23 & 1.29 \\
\hline $\begin{array}{l}\text { I can create and manage my own } \\
\text { account easily }\end{array}$ & $2 \%$ & $1 \%$ & $2 \%$ & $80 \%$ & $15 \%$ & 4.7 & 0.74 \\
\hline $\begin{array}{l}\text { The generator helps me to design } \\
\text { assessment within the learning } \\
\text { object. }\end{array}$ & $2 \%$ & $8 \%$ & $5 \%$ & $55 \%$ & $30 \%$ & 4.28 & 1.01 \\
\hline $\begin{array}{l}\text { I can store my own learning } \\
\text { objects and publish them }\end{array}$ & $6 \%$ & $4 \%$ & $5 \%$ & $57 \%$ & $28 \%$ & 4.26 & 1.12 \\
\hline $\begin{array}{l}\text { I can easily upload my files to } \\
\text { the generator }\end{array}$ & $8 \%$ & $8 \%$ & $4 \%$ & $58 \%$ & $22 \%$ & 4.14 & 1.28 \\
\hline
\end{tabular}


Developing A Digital Knowledge Platform Based on Educational and Technical Standards to Design Auto-Produced E-Learning Objects in Sultanate of Oman

Dr. Nader Shemy, Dr. Walid Aboraya, Dr. Sameh Said, Dr. Muna Alkalbani, Naglaa Shehata, Baraa Abdelhady

\begin{tabular}{|c|c|c|c|c|c|c|c|}
\hline $\begin{array}{l}\text { The generator accepts various } \\
\text { types of multimedia content }\end{array}$ & $7 \%$ & $3 \%$ & $5 \%$ & $51 \%$ & $34 \%$ & 4.19 & 1.13 \\
\hline $\begin{array}{l}\text { I feel that the interface is user- } \\
\text { friendly }\end{array}$ & $2 \%$ & $1 \%$ & $2 \%$ & $75 \%$ & $20 \%$ & 4.67 & 0.73 \\
\hline $\begin{array}{l}\text { It is easy to edit learning objects } \\
\text { that I created. }\end{array}$ & $6 \%$ & $3 \%$ & $1 \%$ & $48 \%$ & $42 \%$ & 4.23 & 1.05 \\
\hline $\begin{array}{l}\text { I can easily download my } \\
\text { learning objects that I created }\end{array}$ & $4 \%$ & $1 \%$ & $5 \%$ & $66 \%$ & $24 \%$ & 4.47 & 0.94 \\
\hline $\begin{array}{l}\text { Choosing among design } \\
\text { templates is very useful to me. }\end{array}$ & $4 \%$ & $5 \%$ & $1 \%$ & $66 \%$ & $24 \%$ & 4.43 & 1.02 \\
\hline $\begin{array}{l}\text { I think that using the learning } \\
\text { objects generator will improve } \\
\text { my teaching. }\end{array}$ & $7 \%$ & $3 \%$ & $5 \%$ & $60 \%$ & $25 \%$ & 4.28 & 1.15 \\
\hline $\begin{array}{l}\text { I can easily view the learning } \\
\text { object that I designed online. }\end{array}$ & $1 \%$ & $2 \%$ & $2 \%$ & $50 \%$ & $45 \%$ & 4.41 & 0.72 \\
\hline $\begin{array}{l}\text { It is easy to access the learning } \\
\text { objects generator. }\end{array}$ & $2 \%$ & $5 \%$ & $3 \%$ & $57 \%$ & $33 \%$ & 4.38 & 0.91 \\
\hline
\end{tabular}

In general, the results show that it is easy for most teachers (87\%) to access the learning objects generator and utilize it. The following is a summary of their replies, as shown in table 1:

95\% of teachers reported that they can easily create and manage their own account, they feel that the interface is user-friendly, and they can easily view the learning objects that they designed online, while 90\% agreed about the following: The learning objects generator will be useful for teachers, it is easy to edit learning 
objects that they created, they can easily download learning objects that they created, and they confirmed that choosing among design templates was very useful to them. Also, $86 \%$ of the teachers reported that the generator can export learning objects in different formats, and $85 \%$ of them agreed about the following: the learning objects generator will solve the teaching and learning problems they are facing, it helps them to design assessment within the learning object, they can store their own learning objects and publish them, the generator accepts various types of multimedia content, and they think that using the learning objects generator will improve their teaching. And $80 \%$ of them agreed that they can easily upload their files to the generator. Moreover, $75 \%$ of the teachers reported that there is a good accessible space for communication among teachers, and finally $70 \%$ reported that teachers can easily share good practices. Although the latter was agreed by most of the teachers, it was ranked last since teachers were unable to practice communication together in the generator's trial edition.

The results indicate that there are many expected benefits for the Sultanate of Oman as follows: (1) The effective contribution of the Sultanate of Oman in providing a space for sharing and cooperation between Arab countries in the field of Arab eeducational content and continuing to play its pioneering and distinguished national and regional role, (2) development of an Omani digital platform concerned with designing self-produced e-learning objects, in the sense of designing learning objects by users (educators, interested persons and other stakeholders) who do not have knowledge and skills in the design and production process and the technical aspects with minimal time and effort, (3) striving towards maximizing the benefit of Omani cadres in the field of designing and developing interactive electronic content and participating in tangible and valuable contributions to the Omani educational 
community, (4) enabling teachers in the Sultanate of Oman to publish lessons, create assignments, implement educational activities, and share educational content with their students, which helps to achieve high-quality educational outcomes, (5) striving to activate, exchange and share teaching experiences among member of the Omani education community and the Arab countries and enable teachers to communicate with each other and exchange ideas and opinions through multiple technologies, thus contributing to improving the quality of performance within the education community in the Sultanate of Oman, (6) allowing to accommodate institutional or individual initiatives in the field of designing, producing, and making electronic educational content available in the Sultanate of Oman, (7) putting education in the Sultanate of Oman on the Arab and regional map through a platform bearing the Omani character in its knowledge content and in its human cadres in the field of education, (8) keeping pace with the rapid developments in the design, production, and availability of interactive electronic content, and paving the way for a future stage in which e-learning is institutionalized as a parallel or supportive system for learning in its traditional modular form.

\section{Conclusion and Future Work}

The effectiveness of the digital knowledge platform based on the foundations of the educational and technical standards for designing self-produced e-learning objects in the Sultanate of Oman was measured, as the design of objects by users who do not have knowledge and skills specially in the educational design, production and artistic processes, as it is based on the idea of the "Wizard", which allows any user to design and produce e-learning objects in the least time and effort without the need for special skills. This platform was developed on the foundations and principles of 
the relevant learning theories to reach an easy-to-use mechanism for designing and producing electronic learning objects for workers and those interested in the teaching and learning processes in Omani and Arab educational institutions. The effectiveness of the platform was measured, including its design, production, and availability mechanism to determine the ease of access, use and effectiveness from the point of view of the target sample, which is 100 teachers, to reach a complete and comprehensive perception based on specialized standards and global experiences and on the results of actual use of the opinions of the study sample, in a manner consistent with the study aims.

\section{Acknowledgements}

The research leading to these results has received funding from the Research Council (TRC) of the Sultanate of Oman under the Block Funding Program. TRC Block Funding Agreement No [BFP/RGP/EHR/18/159]. 
Developing A Digital Knowledge Platform Based on Educational and Technical Standards to Design Auto-Produced E-Learning Objects in Sultanate of Oman

Dr. Nader Shemy, Dr. Walid Aboraya, Dr. Sameh Said, Dr. Muna Alkalbani, Naglaa Shehata, Baraa Abdelhady

\section{References}

Abdel-Fattah, M. A., EMAM, O. E., \& Abdel-Hady, B. A. (2019). Developing Production Process of e-learning Courses: A four Phase Model. International Journal of Applied Engineering Research, 14(10), 2347-2358.

Alkhalaf, S., Drew, S., \& Alhussain, T. (2012). Assessing the impact of e-learning systems on learners: A survey study in the KSA. Procedia-Social and Behavioral Sciences, 47, 98-104.

Cakiroglu, U., Baki, A., \& Akkan, Y. (2012). The Effects of Using Learning Objects in Two Different Settings. Turkish Online Journal of Educational Technology-TOJET, 11(1), 181191.

Castro, M. D. B., \& Tumibay, G. M. (2021). A literature review: efficacy of online learning courses for higher education institution using meta-analysis. Education and Information Technologies, 26(2), 1367-1385.

Crisan, G. C. (2020, January). From Digital Learning Resources to Adaptive Learning Objects: An Overview. In Modelling and Development of Intelligent Systems: 6th International Conference, MDIS 2019, Sibiu, Romania, October 3-5, 2019, Revised Selected Papers (Vol. 1126, p. 18). Springer Nature.

Derntl, M., \& Calvo, R. A. (2011). E-learning frameworks: facilitating the implementation of educational design patterns. International Journal of Technology Enhanced Learning, 3(3), 284-296.

Dolgopolovas, V. (2018). Software learning objects for scientific computing education: teaching scientific inquiry with recurrence based stochastic models (Doctoral dissertation, Vilniaus universitetas).

Gable, G. G., Sedera, D., \& Chan, T. (2008). Re-conceptualizing information system success: The IS-impact measurement model. Journal of the association for information systems, 9(7), 18. 
المجلد الخامس (العدد السادس)

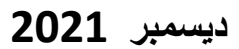

المجلة الدولية للمناهج والتربية التكنولوجية

IJCTE

Goodsett, M. (2020). Assessing the Potential for Critical Thinking Instruction in Information Literacy Online Learning Objects Using Best Practices. Communications in Information Literacy, 14(2), 227-254.

Hsbollah, H. M. (2009). E-learning adoption: the role of relative advantages, trialability and academic specialisation. Campus-Wide Information Systems.

Kamba, M. (2009). Problems, challenges and benefits of implementing e-learning in Nigerian universities: An empirical study. International Journal of Emerging Technologies in Learning (iJET), 4(1), 66-69.

Lorenzetti, J. (2013). Academic administration-running a MOOC: Secrets of the world's largest distance education classes. Magna Publication, Wisconsin.

Morales, V. T., Mendez, N. D. D., \& Rojas, L. F. L. (2017, October). Towards a model of adaptive and accessible repositories of digital educational resources: FROAC case. In 2017 Twelfth Latin American Conference on Learning Technologies (LACLO) (pp. 1-5). IEEE.

Mourão, A. B., \& Netto, J. F. D. M. (2019). Inclusive Model Application Using Accessible Learning Objects to Support the Teaching of Mathematics. Informatics in Education, 18(1), 213-226.

Nesbit, J. C., \& Li, J. (2004, July). Web-based tools for learning object evaluation. In International conference on education and information systems: Technologies and Applications (pp. 2125).

Onofrei, G., \& Ferry, P. (2020). Reusable learning objects: a blended learning tool in teaching computer-aided design to engineering undergraduates. International Journal of Educational Management.

Prasetya, A. (2021). Electronic Module Development with Project Based Learning in Web Programming Courses. International Journal of Computer and Information System (IJCIS), 2(3), 69-72. 
Developing A Digital Knowledge Platform Based on Educational and Technical Standards to Design Auto-Produced E-Learning Objects in Sultanate of Oman

Dr. Nader Shemy, Dr. Walid Aboraya, Dr. Sameh Said, Dr. Muna Alkalbani, Naglaa Shehata, Baraa Abdelhady

Samsuri, N. N., Nadzri, F. A., \& Rom, K. B. M. (2014). A study on the student's perspective on the effectiveness of using e-learning. Procedia-Social and Behavioral Sciences, 123, 139144.

Sek, Y. W., Law, C. Y., \& Lau, S. H. (2012). The effectiveness of learning objects as alternative pedagogical tool in laboratory engineering education. International Journal of e-Education, e-Business, e-Management and e-Learning, 2(2), 145.

Spitz, B. (2020). Creating, Using, and Remixing Online Learning Objects and Multimodal Lesson Plans for Asynchronous and Synchronous Learning.

Topali, P., \& Mikropoulos, T. A. (2021). Scratch-based learning objects for novice programmers: exploring quality aspects and perceptions for primary education. Interactive Learning Environments, 1-16.

Turel, Y. K., \& Gürol, M. (2011). Comprehensive evaluation of learning objects-enriched instructional environments in science classes. Contemporary Educational Technology, 2(4), 264-281.

Vargo, J., Nesbit, J. C., Belfer, K., \& Archambault, A. (2003). Learning object evaluation: computer-mediated collaboration and inter-rater reliability. International Journal of Computers and Applications, 25(3), 198-205.

Vlad, T., Pitică, D., \& Rajmond, J. (2012, October). Implementation of interactive communicational elements on e-learning educational platforms. In 2012 IEEE 18th International Symposium for Design and Technology in Electronic Packaging (SIITME) (pp. 347-350). IEEE.

Zervas, P., Tsourlidaki, E., Cao, Y., Sotiriou, S., Sampson, D. G., \& Faltin, N. (2016). A study on the use of a metadata schema for characterizing school education STEM lessons plans by STEM teachers. Journal of Computing in Higher Education, 28(3), 389-405. 